\title{
РОЗВИТОК ТВОРЧИХ ЗДІБНОСТЕЙ АРТ-ЗАСОБАМИ В ДОШКІЛЬНОМУ ВІЦІ
}

Стаття присвячена особливостям використання арт-засобів, як методу розвитку творчих здібностей в дошкільному віиі. Здійснено спробу аналізу можливостей і функиій дитячої гри, засобів для малювання $і$ ліпки, як інструменту позитивного наповнення дитячої особистості. Висвітленні основні методи роботи дитячих психологів, психологів в системі освіти, а також, роль роботи батьків з дітьми $i$ їх вплив на формування дитячої системи сприйняття світу. Вказано, на взаємозалежність активного розвитку дитячої творчості і продуктивність навчання і успішність дитини в майбутньому, легке вирішення нею задач.

Ключові слова: творчість, розвиток здібностей, розвиток особистості, арт - терапія, арттерапевтичні засоби, ізотерапія, ігрова терапія.

Статья посвящена особенностям использования арт - средств, как метода развития творческих способностей в дошкольном возрасте. Проведён анализ возможностей и функиий детской игры, средств для рисования и лепки, как инструмента положительного наполнения детской личности. Рассмотрены основные методы работы детских психологов, психологов в системе образования, а также роль работы родителей с детьми и их влияние на формирование детской системы восприятия мира. Указано, на взаимозависимость активного развития детского творчества и продуктивность обучения и успеваемость ребенка в будущем, легкое решение им задач.

Ключевые слова: творчество, развитие способностей, развитие личности, арт - терапия, арт - терапевтические средства, изотерапия, игровая терапія.

Постановка проблеми. Творчий потенціал $\epsilon$ актуальним в сучасному суспільстві і $\epsilon$ необхідним в будь якій професії, тому важливо розвивати його в індивіда, ще з раннього дитинства. Майже всі батьки думають, що для того, щоб їх дитина досягла успіхів в майбутньому, важливі: пам'ять, мислення, сенсорні канали сприйняття, саме тому творчості дитини відводиться останнє місце. Однак, якщо в дошкільника будуть добре розвинені творчі нахили, то надалі йому буде легше сприймати і засвоювати предмети навчальної програми, вже маючи до кожного явища і поняття, свій особливий творчий підхід.

Навіть якщо, надалі дитина не стане відомим письменником, музикантом або художником, все одно їй стане в нагоді творче мислення, адже це основа креативності, за допомогою якої, вона буде вирішувати ті життєві задачі, які будуть ставати в неї на шляху. Далеко не все залежить від природніх задатків: важливо вміти розвивати в собі нові здібності.

Метою нашого повідомлення $\epsilon$ розкриття особливостей використання та специфіки застосування арт-терапевтичних прийомів, як засобів розвитку творчих здібностей дітей дошкільного віку.

Аналіз останніх досліджень 3 даної проблематики показав, що творчі здібності людини виражаються в ії умінні знаходити особливий погляд на щось звичне і повсякденне. Обов'язковими компонентами творчих здібностей $є$ творча уява і творче мислення. Дошкільний вік найбільш сприятливий для формування творчої активної особистості. Саме в цей час відбуваються прогресивні 
зміни в багатьох сферах, удосконалюються психічні процеси (увага, пам'ять, сприйняття, мислення, мова, уява), активно розвиваються особистісні якості, а на їх основі - здатності і схильності [4].

Виклад основного матеріалу. У дошкільному навчальному закладі творчість розвивається через різні види діяльності дитини, такі як: ігрова, комунікативна, продуктивна i iнші. Різноманітність методів продиктована багатогранністю процесу засвоєння системи знань, оволодінням основами наук, в які входить в першу чергу гра, будучи одночасно і провідним видом діяльності даного віку. Сюжетно-рольові та театралізовані ігри, ігри-експериментування, ігри-забави і т.д. - всі вони спрямовані на формування творчого потенціалу дошкільника. Але формування творчих здібностей буде досягнуто лише при дотриманні певних умов, таких як: ранній початок творчого розвитку, свобода у виборі видів діяльності і їх різноманітність, створення сприятливого розвивального середовища в дитячому дошкільному закладі, підтримання постійного інтересу до творчої діяльності та інших [2].

Будь-який дорослий, буде це педагог, чи один з батьків $є$ в такий період життя дитини «гончарем, а дитина - глиною в його руках» i, якщо скористатись цим сприятливим періодом, який ми називаємо - дитинство, можна спробувати здійснити вплив на формування особистості, яка в майбутньому зможе творчо підходити до вирішення проблем, і різноманітних задач. Наприклад, спостерігаючи 3 дитиною за листом рослини, можна показати їй прожилки, форму і розмір листа і який різний він з кожного боку на дотик. Можна сказати, що здатність дитини до сприйняття світу буде розвиватися, якщо дорослі, навчать її помічати найдрібніші деталі навколишнього середовища. Ця здатність дуже важлива для розумового розвитку малюка - адже, допитливість дитини легко використовувати, і якщо вона навчиться уважно спостерігати і оцінювати явища природи, навіть, самі крихітні i, здавалося б, незначні деталі, які потім зможуть розповісти ій багато цікавого [3]. Наприклад, можна підібрати картинку, яка зображує сім'ю, відпочиваючу з своїм улюбленцем на березі річки. Запитати дитину, що вона думає про зображення: скільки днів сім'я на відпочинку, як змінюється все навколо, через те що собака з ними, чи тепла вода в річці, хто може вийти з лісу, про що думають діти? Використовуючи свої здібності спостерігати і знайшовши, відповіді на запитання, відпускаючи, свої фантазії, дитина, обов'язково, відповість на ці запитання. У цей момент ви зможете насолодитися фантазією дитини, адже щоб відповісти на ці питання, можна застосувати гру [2].

Досить продуктивним інструментом, для реалізації і розвитку дитячої творчості є малювання. Малювання для дитини - своєрідна форма пізнання реальної дійсності, навколишнього світу, осягнення художнього мистецтва, і тому вимагає поглибленого вивчення, прогнозування і корекції навчання дітей. Малювання $є$ чи не найбільш цікавим видом діяльності дітей дошкільного віку. Нам потрібно вміти гратися, малювати, проводити час з дітьми, адже спільна творчість дітей і дорослих грає важливу роль в розвитку їх творчих здібностей. Безумовно, спільна творчість, яка може бути одним з арт-терапевтичних методів, роботи з дошкільниками дає безліч плюсів, серед яких: розвиток глибокої взаємної довіри, і збагачення відносин дітей та батьків, ознайомлення 3 основами ефективної праці, полегшення процесу соціалізації дошкільника, нейтралізація тиску авторитету батьків, висловлення дитиною свого власного «Я», і усвідомлення себе як члена сім'ї, тощо. Розвиваються естетичні почуття - малюк вчиться бачити і цінувати прекрасне, створюється сприятлива атмосфера для розвитку творчих здібностей не тільки дітей, а й дорослих. Будуються сприятливі умови, для розвитку цілісної і гармонічної особистості [4]. На спільних заняттях 3 батьками дитина отримує емоційну розрядку, завдяки чому надлишок енергії йде в конструктивне спрямування, не залишаючи сил для капризів і пустощів. Творчою діяльністю краще починати займатися тоді, коли малюк вже впевнено зможе тримати в руках невеликі предмети. Творча взаємодія з батьками дарує малюку безпечний простір для матеріалізації своїх фантазій, в результаті чого дитина починає мислити нестандартно. Спочатку це проявиться у виникненні сміливих асоціацій при перегляді пересічних предметів. А після малюк навчиться знаходити оригінальні підходи до вирішення будь-яких повсякденних завдань [7]. Головним $\epsilon$ те, що спільна творчість дітей i батьків не повинна викликати жодних негативних емоцій. Тому приступати до занять слід 3 хорошим настроєм.

Для того щоб визначити які арт-терапевтичні методи і прийоми використовують у своїй роботі сучасні педагоги і психологи, ми проаналізували і узагальнили досвід вітчизняних педагогів і психологів-практиків, що дозволило виділити наступні методи і прийоми роботи: ігротерапія, казкотерапія, зображувальна терапія, терапія піском, робота 3 пластичними матеріалами. У будь якому з своїх напрямків арт-терапія полягає в гармонізації розвитку особистості через розвиток здатності самовираження і самопізнання. Вона безпечно зцілює психіку, знайомить з навколишнім світом, дозволяє побачити світ навколо себе прекрасним і гостинним. Арт-терапія пропонує дитині висловити свої емоції, почуття за допомогою ліплення, малювання і т.д. Наприклад в фарбах одягу:

Випуск 11, 2018. Збірник наукових праць РДГУ 
можливо, це і $є$ той самий творчий хаос; спочатку - вивчіть колір, потім - познайомтеся 3 геометричними фігурами, покажіть, як створюється малюнок, а потім просто спостерігайте за результатами [2].

Більш детально розглянемо арт-терапевтичні напрямки i їх значення в розвитку творчіх здібностей дитини. Перш за все зупинимося на ігротерапії. Ігротерапія - це вид непродуктивної діяльності, де мотив лежить не в результаті їі, а в самому процесі. У дітей дошкільного віку гра $\epsilon$ основним видом діяльності. В іграх діти наслідують трудовудіяльністьі дорослих, приймають на себе різні соціальні ролі. Уже на цьому етапі відбувається диференціація за статевою ознакою. В іграх проявляються індивідуальні та вікові особливості дітей [6]. На думку Нестерової В. А, основна мета ігрової терапії - допомогти дитині висловити свої переживання найбільш прийнятним для неї способом - через гру, а також проявити творчу активність у вирішенні складних життєвих ситуацій. Ігри можна проводити в будь-який вільний час як індивідуально, так і з підгрупою дітей, але при цьому необхідно дотримуватися певних правил.

Казкотерапія дієвий засіб розвитку творчих здібностей дитини. Як зазначає В. Лучанська навіть казки створені психотерапевтом чи психологом з метою самотерапії приносять користь не тільки автору. Їх з інтересом слухають інші діти, учні, пацієнти. Створена казка починає жити самостійним життям [4]. Додатково в рамках ігрової терапії та казкотерапії можна використовувати елементи музикотерапії. Музикотерапія - це робота з музичними інструментами та творами з метою використання, як засобу розвитку музичних і рухових здібностей дітей, ігрового тренінгу розвитку психічних процесів: уваги, пам'яті, волі, творчої уяви і фантазії, як засіб розслаблення, переключення уваги або підвищення психофізичного тонусу і т.д., в самих різних формах організації педагогічного процесу в дитячому дошкільному закладі [1].

Зображувальна терапія це арт-терапія малюванням. Один із основних методів сучасної арттерапії - лікування та розвиток образотворчою творчістю, в першу чергу малюванням. В їі основі лежить особлива «сигнальна система кольорового зображення», згідно з якою за допомогою кольору учасник технології сигналізує про свій емоційний стан. Сучасна зображувальна терапія - це в основному процес художньої творчості. Процес і результат малювання аналізується за такими параметрами: швидкість заповнення листа, характер ліній i форм, зображених на малюнку, i переважаючи кольори і тони [4]. Терапія піском або ж гра з піском, має на меті допомогти індивіду без слів виразити свої емоції, відчуття, переживання. Також, пісок це природній матеріал, що забезпечує чуттєвий досвід дитини, розвиваючи сенсорні здібності та аналізатори. У процесі гри 3 піском, у дітей розвивається мислення, вміння проводити аналогії, узагальнювати та робити висновки, і все це за допомогою пошуку та дослідницькій діяльності. Ще одним засобом арт-терапії, що можна застосовувати в дошкільному освітньому закладі є робота 3 пластичними матеріалами (глина, пластилін, солоне тісто). За допомогою різного матеріалу дитина розвиває сенсорну чутливість, дрібну моторику рук, образне мислення і фантазію, концентрацію уваги та здатність до планування своєї діяльності. Арт-терапевтичні засоби виступають, як ефективним інструментом розвитку творчого потенціалу, так і безпечною технікою корекції емоційного стану дитини. Можливості мистецтва для досягнення позитивних змін в дошкільному віці не вичерпуються наведеними прикладами, однак привертають увагу до арт-терапії як перспективної форми роботи 3 різною проблематикою.

Висновки та перспективи подальших розвідок. Арт-засоби можуть бути потужним інструментом у розвитку дитячої творчості і дитячого інтелекту. У залежності від можливостей $\mathrm{i}$ бажань дітей заняття арт-терапією можуть нести розвиваючу, навчальну, виховну функції. Арттерапевтичні засоби представлені у різних формах, а саме: ігротерапії, сюжетно-рольових іграх, рухливих іграх, музикотерапії, казко терапії. Всі вони дозволяють подолати проблеми, що викликають негативні емоції, сприяють посиленню творчої енергії. Використання арт-засобів у спільній роботі з батьками дозволяє налагоджувати глибоку взаємодію довіри, і збагатити відносини дітей та батьків, полегшити процес соціалізації дошкільника, нейтралізувати тиск авторитету батьків, за допомогою чого дитина, може вільно висловити своє власне «Я» та проявити або ж розвинути власні творчі здібності.

\section{Список використаних джерел}

1. Головінський І. Педагогічна психологія / І. Головінський. - Київ : Аканіт, 2003. - 287 с.

2. Кирнарская Д. К. Психология специальных возможностей. Музыкальные возможности / Д. К. Кирнарская. - М., 2004. - 496 с.

3. Киселева М. В. Арт-терапия в роботе с детьми / М. В. Киселева. - М., 2007. - 160 с. 
4. Лучанська В. Проблема креативності в сучасній психології [Електронний ресурс] /

В. Лучанська // Соціальна психологія. - 2012. - Режим доступу : http://www.politik.org.ua.

5. Моляко В. О. Психологія творчості та обдарованості : нові рубежі теорії та практики / В. О. Моляко // Обдарована дитина. - 2007. - № 7. - С. 2-3.

6. Роменець В. А. Психологія творчості / В. А. Роменець. - Київ : Либідь, 2001. - 287 с.

7. Туриніна О. Л. Психологія творчості : навч. посіб. / О. Л. Туриніна. - Київ : МАУП, 2007. $-160 \mathrm{c}$

\section{References}

1. Golovins`ky`j I. Pedagogichna psy`xologiya / I. Golovins`ky`j. - Ky`yiv : Akanit, 2003. - 287 s.

2. Ky`rnarskaya D. K. Psy`xology`ya specy`al'nyx vozmozhnostej. Muzykal’nye vozmozhnosty` / D. K. Ky`rnarskaya. - M., 2004. - $496 \mathrm{~s}$.

3. Ky`seleva M. V. Art-terapy`ya v robote s det`my` / M. V. Ky`seleva. - M., 2007. - $160 \mathrm{~s}$.

4. Luchans`ka V. Problema kreaty`vnosti v suchasnij psy`xologiyi [Elektronny’j resurs] / V. Luchans`ka // Social`na psy`xologiya. - 2012. - Rezhy`m dostupu : http://www.politik.org.ua.

5. Molyako V. O. Psy`xologiya tvorchosti ta obdarovanosti : novi rubezhi teoriyi ta prakty`ky`/V. O. Molyako. // Obdarovana dy`ty`na. - 2007. - № 7. - S. 2-3.

6. Romenecz` V. A. Psy`xologiya tvorchosti / V. A. Romenecz`. - Ky`yiv : Ly`bid`, 2001. - 287 s.

7. Tury`nina O. L. Psy`xologiya tvorchosti : navch. posib. / O. L. Tury`nina. - Ky`yiv : MAUP, 2007. $-160 \mathrm{~s}$.

\section{Lisna THE DEVELOPMENT OF ART CREATIVITY BY FACILITIES IN PRESCHOOL}

The article is devoted to the peculiarities of using different art - supplies, as a development methods of creative abilities in preschool age. The author made an attempt to analyze the possibilities and functions of the play-therapy, the tools for drawing and molding, as an instruments for positive stuffing of the child. It is clear that these basic art-therapeutic tools act as an effective instrument for the development of creativity, as well as safe techniques for correcting the child's emotional sphere.

In the article author tries to cover the main methods of psychologists work, as well as the role of the work of parents with children and their influence on the formation of the children's system of perception of the world. After all, art - tools can be a powerful method in the development of children 's creativity and intelligence. The author summarizes that art therapy classes can carry developing, educational and educational functions depending on the possibilities and desires of children Also, the methods of art allow to overcome the problems that cause negative emotions, which will ultimately allow to throw creative energy. The article reveals the use of art-tools in collaboration with parents allows to develop a deep interaction of trust and to enrich the relations of children and parents, to facilitate the process of socialization of preschoolers, to neutralize the pressure of authority of parents, by which the child can easy express his own self and to show or develop their own creative abilities

The author summarizes that the possibilities of art to achieve positive changes in preschool age are not limited to the examples that were given, but draw attention to art therapy as a promising form of work with different issues.

Key words: creativity, development of abilities, personality development, art therapy, art therapeutic means, play therapy. 